\title{
Salmonella serovar spectrum associated with reptiles in Poland
}

\author{
Tomasz Piasecki, Klaudia Chrząstek, Alina Wieliczko \\ Wrocław University of Environmental and Life Sciences, Faculty of Veterinary Medicine, \\ Department of Epizootiology and Clinic of Bird and Exotic Animals, Wrocław, Poland
}

Received April 1, 2014

Accepted July 23, 2014

\begin{abstract}
This study aimed to evaluate the incidence of Salmonella isolates from a wide variety of reptiles in Poland. A total of 374 faecal samples from chelonians, lizards and snakes were collected between 2009 and 2012. The nested, two-step PCR and multiplex PCR were performed to access the incidence and to characterize Salmonella isolates. Salmonella strains were found in 122 of 374 samples (32.6\%). Among the different reptilian species, Salmonella strains were found in 58 samples from lizards $(38.9 \%), 31$ samples from snakes $(28.7 \%)$ and 33 samples from chelonians $(28.2 \%)$. Of the total of 122 strains, 72 belonged to the species Salmonella enterica subsp. enterica, 20 to the species $S$. enterica subs. salamae or S. enterica subs. houtanae. The incidence of $S$. enterica subs. diarizonae and $S$. enterica subs. indica was low, constituting less than $3.5 \%$ of the examined population. The findings show that reptiles can be considered as a reservoir for Salmonella and hence could pose a zoonotic hazard. In addition, multiplex PCR assay is a rapid, specific and easy-to-perform method and might be applied for rapid screening of large numbers of Salmonella samples.
\end{abstract}

Chelonians, snake, lizard, reptile-associated salmonellosis, zoonotic agent, PCR

Salmonella is an important zoonotic pathogen of economic significance both in humans and animals. Salmonellosis has declined significantly in the EU by almost one half over the period of five years (2004-2009). Moreover, it was reported by European Food Safety Authority (EFSA) that confirmed cases of human salmonellosis in 2011 decreased by $5.4 \%$ compared to 2010. Nevertheless, in 2011 this organism was still the second most frequently reported zoonotic disease in humans, accounting for 95,548 reported cases. The serovars of Salmonella associated most frequently with human illness were $S$. enteritidis and $S$. thyphimurium (EFSA 2013). The continued decreasing trend in human cases reflects the impact of Salmonella control programmes (e. g. in poultry) put in place by EU Member States and the European Commission. However, these control programmes do not apply to reptiles. These animals may harbour a wide variety of Salmonella serotypes in their intestine and can be well adapted to reptilian species with mostly asymptomatic infections (Johnson-Delaney 1996; Woodward et al. 1997; Willis et al. 2002). The increasing popularity of these animals as pets may lead to an increasing number of reptile-associated human salmonellosis cases. Clinical cases of reptile-associated salmonellosis have been reported previously (Weinstein et al. 1995; Friedman et al. 1998; Lakew et al. 2013). Salmonella illness remains a public health problem in the United States and these reptiles are a well-established source of human salmonellosis. It was reported that $6 \%$ of all human Salmonella infection during 1996-1997 in the U.S. were associated with reptiles or amphibians (Mermin et al. 2004). For instance, recently the U.S. Center for Disease Control and Prevention (CDC) published information about eight multistate outbreaks of human Salmonella infections linked to small turtles. A total of 473 persons from 41 states were infected (CDC 2013). The investigations indicated exposure to turtles or their environments (e.g., water from a turtle habitat) was the source of these eight outbreaks

Address for correspondence:

Tomasz Piasecki

Department of Epizootiology and Clinic of Bird and Exotic Animals

Faculty of Veterinary Medicine

Wrocław University of Environmental and Life Sciences

pl. Grunwadzki 45, Wrocław 50-366, Poland

Phone: +48713205325
Fax: +48 713205336
Email: tomasz.piasecki@up.wroc.pl
http://actavet.vfu.cz/ 
(CDC 2013). Little is known about the epidemiological situation regarding Salmonella spp. in reptiles in Poland. The survey done in 1999 in Poland which incorporated over 300,000 animal and food samples showed that the most common serovar of Salmonella was $S$. enteritidis and the percentage of positive results, in other than poultry animals (which include turtles), was 3.6\% (Hoszowski and Wasyl 2002). In addition, Zajac et al. (2013) have shown that carnivore reptiles can carry multidrug and high level ciprofloxacine resistant $S$. Kentucky type ST198 and those animals should be taken into account as a possible vector of human infection.

This study aimed to evaluate the incidence of Salmonella spp. and characterize the isolates from wide variety of reptiles in Poland by means of PCR assay.

\section{Materials and Methods}

A total of 374 samples were collected from different species of reptiles (chelonians, $\mathrm{n}=117$; snakes, $\mathrm{n}=108$, lizards, $\mathrm{n}=149$ ). The list of reptiles tested is shown in Table 2. Faecal samples were collected between 2009 and 2012 from reptiles which were housed in zoos and with private keepers. The detection of Salmonella isolates was performed according to the ISO standard no. 6579:2003/A1:2007. Afterwards, three colonies per plate with characteristics of Salmonella were spread onto nutrient agar (Nutrient Agar, Merck, Germany) for $24 \mathrm{~h}$ at $37^{\circ} \mathrm{C}$ and further identified biochemically. For DNA extraction, all strains were plated on trypticase soy agar (Becton Dickinson) with overnight incubation at $37^{\circ} \mathrm{C}$. Bacterial genomic DNA was then extracted after growth overnight in Luria-Bertani broth (Difco Laboratories, Detroit, MI, USA) by using the Genomic DNA Prep Plus ${ }^{\circledR}$ kit (A\&A Biotechnology, Gdynia, Poland) according to the manufacturer's instructions. DNA was quantitated by spectrophotometry (BioPhotometer, Eppendorf) and stored at $4{ }^{\circ} \mathrm{C}$.

DNA was extracted as described above and then amplified by nested, two-step PCR using the primers $11 \mathrm{~L}$ (AACCATTGCTAAATTGGCGCACAACC) and 15L (GAAATTCCCAGCGGGTACTGGGTACTG), and the nested primers ST12 (CGTCCGGCATGACGATGGTA), and ST13 (ATTCACCGGAACGGCGCCGT) (Aabo et al. 1993; Haedicke et al. 1996). PCR reactions contained 50 ng template DNA, 2.5 U Green Taq polymerase, $10 \times$ PCR buffer, $1.5 \mathrm{mM} \mathrm{MgCl}_{2}, 200 \mu \mathrm{M}$ dNTPs (Fermentas, Vilnius, Lithuania), and 20 pmol of 11L and 15L primers (Genomed, Warszawa, Poland) at a final volume of $25 \mu \mathrm{l}$. Reaction conditions were as follows: initial denaturation $5 \mathrm{~min}$ at $94{ }^{\circ} \mathrm{C}, 40$ cycles of $1 \mathrm{~min}$ at $70{ }^{\circ} \mathrm{C}, 30 \mathrm{~s}$ at $94{ }^{\circ} \mathrm{C}$ and $3 \mathrm{~min}$ at $72{ }^{\circ} \mathrm{C}$. For the nested PCR, $5 \mu \mathrm{l}$ of the first round product and ST12 and ST13 primers (Genomed, Warszawa, Poland) were used. The following cycling conditions were performed: initial denaturation at $94{ }^{\circ} \mathrm{C}$ for $5 \mathrm{~min}$, followed by 30 cycles of $55^{\circ} \mathrm{C}$ for $30 \mathrm{~s}, 72^{\circ} \mathrm{C}$ for $1 \mathrm{~min}$ and $94{ }^{\circ} \mathrm{C}$ for $30 \mathrm{~s}$, and a final extension at $72{ }^{\circ} \mathrm{C}$ for $3 \mathrm{~min}$. Samples which were

Table 1. Oligonucleotide primers and expected band patterns of each Salmonella species or subspecies.

\begin{tabular}{|c|c|c|c|c|c|c|c|c|c|c|}
\hline \multirow{2}{*}{ Primer } & \multirow{2}{*}{ Sequence $\left(5^{\prime}-3^{\prime}\right)$} & \multirow{2}{*}{$\begin{array}{l}\text { Target } \\
\text { gene }\end{array}$} & \multirow{2}{*}{$\begin{array}{l}\text { Product } \\
\text { size (bp) }\end{array}$} & \multicolumn{7}{|c|}{ Salmonella species or subspecies } \\
\hline & & & & I & II & IIIa & IIIb & IV & VI & $\mathrm{V}$ \\
\hline fljB1 & GACTCCATCCAGGCTGAAATCAC & \multirow{2}{*}{$f j B$} & \multirow{2}{*}{848} & \multirow{2}{*}{$\mathrm{d}$} & \multirow{2}{*}{$\mathrm{d}$} & \multirow{2}{*}{\multicolumn{2}{|c|}{+}} & \multirow{2}{*}{\multicolumn{2}{|c|}{+}} & \multirow{2}{*}{+} \\
\hline $\mathrm{fljB} 2$ & CGGCTTTGCTGGCATTGTAG & & & & & & & & & \\
\hline $\operatorname{mdcA} 7$ & GGATGTACTCTTCCATCCCCAGT & \multirow{2}{*}{$m d c A$} & \multirow{2}{*}{728} & & \multirow{2}{*}{+} & \multirow{2}{*}{+} & \multirow{2}{*}{+} & & & \\
\hline$\overline{\mathrm{mdcA}} 8$ & CGTAGCGAGCATCTGGATATCTT & & & & & & & & & \\
\hline gatD P5 & GGCGCCCATTATTATCCTATTAC & \multirow{2}{*}{ gatD } & \multirow{2}{*}{501} & \multirow{2}{*}{+} & \multirow{2}{*}{+} & & & & \multirow{2}{*}{$\mathrm{d}$} & \multirow{2}{*}{+} \\
\hline gatD P6 & CATTTCCCGGCTATTACAGGTAT & & & & & & & & & \\
\hline $\operatorname{stn} \mathrm{fl}$ & CGATCCCTTTCCCGCTATC & \multirow{2}{*}{ stn } & \multirow{2}{*}{179} & \multirow{2}{*}{+} & \multirow{2}{*}{+} & \multirow{2}{*}{+} & \multirow{2}{*}{+} & \multirow{2}{*}{+} & \multirow{2}{*}{+} & \\
\hline $\operatorname{stn} \mathrm{r} 1$ & GGCGAATGAGACGCTTAAG & & & & & & & & & \\
\hline STM4057 f1 & GGTGGCCTCGATGATTCCCG & \multirow{2}{*}{ STM4057 } & \multirow{2}{*}{137} & \multirow{2}{*}{+} & & & & & & \\
\hline STM4057 r1 & CCCACTTGTAGCGAGCGCCG & & & & & & & & & \\
\hline INVA-1 & ACAGTGCTCGTTTACGACCTGAAT & \multirow{2}{*}{ invA } & \multirow{2}{*}{244} & \multirow{2}{*}{+} & + & + & + & + & + & + \\
\hline INVA-2 & AGACGACTGGTACTGATCGATAAT & & & & & & & & & \\
\hline
\end{tabular}

d - differs among strains 
positive for Salmonella were then examined by multiplex PCR amplification based on formula described previously by Lee et al. (2009). The list of primers used in multiplex PCR which give unique results for each subspecies of Salmonella strains are shown in Table 1. The PCR reactions were set up as $25 \mu 1$ reaction containing 50 ng template DNA, $1 \mathrm{U}$ Green Taq polymerase, $10 \times$ PCR buffer, $1.5 \mathrm{mM} \mathrm{MgCl}, 200 \mu \mathrm{M}$ dNTP and 20 pmol of each primers using the following PCR conditions: denaturation, $1 \mathrm{~min}$ at $95^{\circ} \mathrm{C}$; annealing, $1 \mathrm{~min}$ at $60{ }^{\circ} \mathrm{C}$; and extension $1 \mathrm{~min}$ at $72{ }^{\circ} \mathrm{C}$ for 40 cycles, followed by a final extension at $72{ }^{\circ} \mathrm{C}$ for $15 \mathrm{~min}$. The DNA amplification products were resolved on a $1.5 \%$ agarose gel stained with ethidium bromide and visualised using the Gel-Doc UV transilluminator system (Biorad, Warszawa, Poland) with Quantity-One software (Biorad, Warszawa, Poland).

\section{Results}

The incidence of Salmonella in different species of reptiles is shown in Table 2. Salmonella strains were found in 122 of 374 samples (32.6\%). Among the different reptilian species Salmonella strains were found in 58 samples from lizards (38.9\%), 31 samples from snakes (28.7\%) and 33 samples from chelonians (28.2\%). Of the total of 122 strains, 72 belonged to the species Salmonella enterica subsp. enterica (19 of 33 chelonians carriers, 19/31 snakes and 34/58 lizards) and as a result this serotype predominated in all of the reptiles tested $(59.02 \%)$. The second most frequently reported serotypes were $S$. enterica subs. salamae and S. enterica subs. houtanae (both of 16.39\%). However, we found differences in incidence between those serotypes. S. enterica subs. salamae was recorded in 8 of 31 snake carriers (25.81\%) compared to chelonians and lizards $(18.18 \%$ and $10.34 \%$, respectively) whereas the percentage of S. enterica subs. houtanae samples was higher in lizards $(25.86 \%)$ compared to chelonians $(15.15 \%)$ and, interestingly, this species was not detected in snakes (Fig. 1). The incidence of S. enterica subs. diarizonae and S. enterica subs. indica was low, constituting less than $3.5 \%$ of the examined population. Five strains were non-typeable (NT).

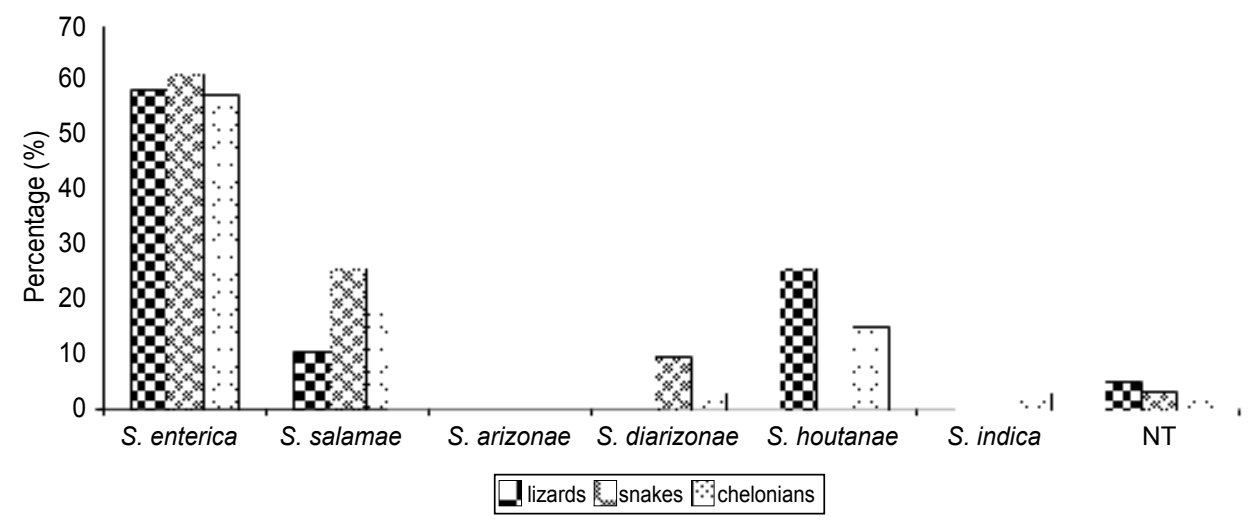

Fig. 1. The incidence of Salmonella subspecies in reptiles NT - non-typeable

\section{Discussion}

Reptiles are very common carriers of Salmonella and can be infected without showing any symptoms, thus, posing a hazard in terms of a zoonosis. The increasing popularity of these animals as pets worldwide may lead to an increased number of reptile-associated human salmonellosis cases. This survey has confirmed moderate to high prevalence of Salmonella strains in reptiles in Poland, ranging from around $28.0 \%$ in snakes and chelonians to almost 39\% in lizard. In Central Europe (Germany and Austria), Salmonella 
Table 2. Incidence of Salmonella spp. in different species of reptiles.

\begin{tabular}{|c|c|c|c|c|c|c|c|c|c|}
\hline & \multicolumn{2}{|c|}{ Number of samples } & \multicolumn{6}{|c|}{ Salmonella } & \multirow[b]{2}{*}{ NT } \\
\hline & investigated & positive & $\begin{array}{l}\text { enterica } \\
\text { (I) }\end{array}$ & $\begin{array}{l}\text { salamae } \\
\text { (II) }\end{array}$ & $\begin{array}{c}\text { arizonae } \\
\text { (IIIa) }\end{array}$ & $\begin{array}{l}\text { diarizonae } \\
\text { (IIIlb) }\end{array}$ & $\begin{array}{c}\text { houtanae } \\
\text { (IV) }\end{array}$ & $\begin{array}{c}\text { indica } \\
\text { (VI) }\end{array}$ & \\
\hline $\begin{array}{l}\text { Order Testudines } \\
\text { (chelonians) }\end{array}$ & 117 & 33 & 19 & 6 & 0 & 1 & 5 & 1 & 1 \\
\hline Family Chelidae & & & & & & & & & \\
\hline $\begin{array}{l}\text { Chelus fimbriatus } \\
\text { Family Pelomedusidae }\end{array}$ & 3 & 1 & 0 & 1 & 0 & 0 & 0 & 0 & 0 \\
\hline $\begin{array}{l}\text { Pelomedusa subrufa } \\
\text { Family Chelydridae }\end{array}$ & 1 & 0 & 0 & 0 & 0 & 0 & 0 & 0 & 0 \\
\hline $\begin{array}{l}\text { Chelydra serpentina } \\
\text { Family Emydidae }\end{array}$ & 1 & 1 & 0 & 0 & 0 & 0 & 1 & 0 & 0 \\
\hline Cuora amboinensis & 1 & 0 & 0 & 0 & 0 & 0 & 0 & 0 & 0 \\
\hline $\begin{array}{l}\text { Trachemys scripta } \\
\text { Family Geoemydidae }\end{array}$ & 14 & 6 & 3 & 1 & 0 & 1 & 1 & 0 & 0 \\
\hline Geoemyda spenglei & 2 & 0 & 0 & 0 & 0 & 0 & 0 & 0 & 0 \\
\hline $\begin{array}{l}\text { Heosemys grandis } \\
\text { Family Testudinidae }\end{array}$ & 1 & 0 & 0 & 0 & 0 & 0 & 0 & 0 & 0 \\
\hline Astrochelys radiata & 1 & 0 & 0 & 0 & 0 & 0 & 0 & 0 & 0 \\
\hline Chelonoidis nigra & 1 & 0 & 0 & 0 & 0 & 0 & 0 & 0 & 0 \\
\hline Geochelone denticulata & 2 & 0 & 0 & 0 & 0 & 0 & 0 & 0 & 0 \\
\hline Geochelone elegans & 1 & 0 & 0 & 0 & 0 & 0 & 0 & 0 & 0 \\
\hline Geochelone pardalis & 1 & 1 & 1 & 0 & 0 & 0 & 0 & 0 & 0 \\
\hline Geochelone sulcata & 1 & 0 & 0 & 0 & 0 & 0 & 0 & 0 & 0 \\
\hline Indotestudo elongata & 1 & 0 & 0 & 0 & 0 & 0 & 0 & 0 & 0 \\
\hline Kinixys homeana & 1 & 0 & 0 & 0 & 0 & 0 & 0 & 0 & 0 \\
\hline Kinixys nogueyi & 3 & 0 & 0 & 0 & 0 & 0 & 0 & 0 & 0 \\
\hline Stigmochelys pardalis & 1 & 0 & 0 & 0 & 0 & 0 & 0 & 0 & 0 \\
\hline Testudo graeca & 4 & 1 & 0 & 0 & 0 & 0 & 1 & 0 & 0 \\
\hline Testudo hermanni & 25 & 6 & 5 & 0 & 0 & 0 & 1 & 0 & 0 \\
\hline Testudo horsfieldi & 34 & 9 & 6 & 2 & 0 & 0 & 1 & 0 & 0 \\
\hline Testudo kleinamani & 14 & 7 & 4 & 1 & 0 & 0 & 0 & 1 & 1 \\
\hline Family Carettochelyidae & & & & & & & & & \\
\hline Carettochelys insculpta & 2 & 1 & 0 & 1 & 0 & 0 & 0 & 0 & 0 \\
\hline Family Kinosternidae & & & & & & & & & \\
\hline Sternotherus odoratus & 2 & 0 & 0 & 0 & 0 & 0 & 0 & 0 & 0 \\
\hline Suborder Serpentes (snakes) & 108 & 31 & 19 & 8 & 0 & 3 & 0 & 0 & 1 \\
\hline Family Boidae & & & & & & & & & \\
\hline Acanthophis dumerilii & 1 & 0 & 0 & 0 & 0 & 0 & 0 & 0 & 0 \\
\hline Boa constrictor & 35 & 9 & 6 & 2 & 0 & 0 & 0 & 0 & 1 \\
\hline Epicrates cenchria & 6 & 3 & 2 & 0 & 0 & 1 & 0 & 0 & 0 \\
\hline Epicrates striatus & 2 & 0 & 0 & 0 & 0 & 0 & 0 & 0 & 0 \\
\hline Eryx colubrimus & 1 & 1 & 0 & 1 & 0 & 0 & 0 & 0 & 0 \\
\hline Morelia spilota & 1 & 0 & 0 & 0 & 0 & 0 & 0 & 0 & 0 \\
\hline Morelia viridis & 15 & 8 & 5 & 2 & 0 & 1 & 0 & 0 & 0 \\
\hline Python molurus & 3 & 0 & 0 & 0 & 0 & 0 & 0 & 0 & 0 \\
\hline Python regius & 13 & 4 & 3 & 1 & 0 & 0 & 0 & 0 & 0 \\
\hline Sanzinia madagascariensis & 2 & 0 & 0 & 0 & 0 & 0 & 0 & 0 & 0 \\
\hline
\end{tabular}




\begin{tabular}{|c|c|c|c|c|c|c|c|c|c|}
\hline & \multicolumn{2}{|c|}{ Number of samples } & \multicolumn{6}{|c|}{ Salmonella } & \multirow[b]{2}{*}{ NT } \\
\hline & investigated & positive & $\begin{array}{l}\text { enterica } \\
\text { (I) }\end{array}$ & $\begin{array}{c}\text { salamae } \\
\text { (II) }\end{array}$ & $\begin{array}{c}\text { arizonae } \\
\text { (IIIa) }\end{array}$ & $\begin{array}{c}\text { diarizonae } \\
\text { (IIIb) }\end{array}$ & $\begin{array}{c}\text { houtanae } \\
\text { (IV) }\end{array}$ & $\begin{array}{c}\text { indica } \\
\text { (VI) }\end{array}$ & \\
\hline \multicolumn{10}{|l|}{ Family Colubridae } \\
\hline Elaphe guttatus & 10 & 0 & 0 & 0 & 0 & 0 & 0 & 0 & 0 \\
\hline Elaphe obsoleta & 2 & 0 & 0 & 0 & 0 & 0 & 0 & 0 & 0 \\
\hline Elaphe radiata & 1 & 0 & 0 & 0 & 0 & 0 & 0 & 0 & 0 \\
\hline Lamprophis fuliginosus & 4 & 1 & 0 & 0 & 0 & 1 & 0 & 0 & 0 \\
\hline Bogertophis subocularis & 2 & 1 & 1 & 0 & 0 & 0 & 0 & 0 & 0 \\
\hline Coluber hippocrepis & 2 & 2 & 1 & 1 & 0 & 0 & 0 & 0 & 0 \\
\hline Lampropeltis triangulum & 1 & 0 & 0 & 0 & 0 & 0 & 0 & 0 & 0 \\
\hline Thamnophis marcianus & 2 & 0 & 0 & 0 & 0 & 0 & 0 & 0 & 0 \\
\hline Ahaetulla mycterizans & 1 & 0 & 0 & 0 & 0 & 0 & 0 & 0 & 0 \\
\hline Orthriophis taeniurus & 3 & 2 & 1 & 1 & 0 & 0 & 0 & 0 & 0 \\
\hline \multicolumn{10}{|l|}{ Family Viperidae } \\
\hline Cryptelytrops albolabris & 1 & 0 & 0 & 0 & 0 & 0 & 0 & 0 & 0 \\
\hline \multicolumn{10}{|l|}{ Order Squamata } \\
\hline Suborder Lacertilia ( lizards) & 149 & 58 & 34 & 6 & 0 & 0 & 15 & 0 & 3 \\
\hline \multicolumn{10}{|l|}{ Family Agamidae } \\
\hline Agama agama & 1 & 1 & 0 & 0 & 0 & 0 & 1 & 0 & 0 \\
\hline $\begin{array}{l}\text { Gonocephalus } \\
\text { chamaeleontinus }\end{array}$ & 3 & 0 & 0 & 0 & 0 & 0 & 0 & 0 & 0 \\
\hline Pogona vitticeps & 25 & 13 & 12 & 0 & 0 & 0 & 1 & 0 & 0 \\
\hline Physignathus lesueurii & 1 & 1 & 1 & 0 & 0 & 0 & 0 & 0 & 0 \\
\hline Physignathus cocincinus & 7 & 0 & 0 & 0 & 0 & 0 & 0 & 0 & 0 \\
\hline Uromastyx aegyptia & 4 & 1 & 1 & 0 & 0 & 0 & 0 & 0 & 0 \\
\hline \multicolumn{10}{|l|}{ Family Chamaeleonidae } \\
\hline Chamaeleo calyptratus & 1 & 0 & 0 & 0 & 0 & 0 & 0 & 0 & 0 \\
\hline \multicolumn{10}{|l|}{ Family Cordylidae } \\
\hline Cordylus tropidosternum & 2 & 0 & 0 & 0 & 0 & 0 & 0 & 0 & 0 \\
\hline \multicolumn{10}{|l|}{ Family Corytophanidae } \\
\hline Basiliscus vittatus & 2 & 1 & 1 & 0 & 0 & 0 & 0 & 0 & 0 \\
\hline Laemanctus longipes & 1 & 1 & 1 & 0 & 0 & 0 & 0 & 0 & 0 \\
\hline \multicolumn{10}{|l|}{ Family Crotaphytidae } \\
\hline Crotaphytus collaris & 3 & 3 & 3 & 0 & 0 & 0 & 0 & 0 & 0 \\
\hline \multicolumn{10}{|l|}{ Family Geconidae } \\
\hline Coleonyx elegans & 1 & 0 & 0 & 0 & 0 & 0 & 0 & 0 & 0 \\
\hline Gekko petricolus & 1 & 0 & 0 & 0 & 0 & 0 & 0 & 0 & 0 \\
\hline Gekko vittatus & 2 & 2 & 2 & 0 & 0 & 0 & 0 & 0 & 0 \\
\hline Eublepharis macularius & 13 & 5 & 4 & 0 & 0 & 0 & 1 & 0 & 0 \\
\hline Hemitheconyx caudicinctus & 2 & 1 & 0 & 0 & 0 & 0 & 1 & 0 & 0 \\
\hline Homopholis fasciata & 1 & 0 & 0 & 0 & 0 & 0 & 0 & 0 & 0 \\
\hline Phelsuma madagascariensis & 4 & 3 & 2 & 1 & 0 & 0 & 0 & 0 & 0 \\
\hline Rhacodactylus auriculatus & 1 & 1 & 0 & 0 & 0 & 0 & 1 & 0 & 0 \\
\hline Tarentola annularis & 2 & 1 & 0 & 1 & 0 & 0 & 0 & 0 & 0 \\
\hline Tarentola mauritanica & 4 & 1 & 0 & 1 & 0 & 0 & 0 & 0 & 0 \\
\hline
\end{tabular}




\begin{tabular}{|c|c|c|c|c|c|c|c|c|c|}
\hline & \multicolumn{2}{|c|}{ Number of samples } & \multicolumn{6}{|c|}{ Salmonella } & \multirow[b]{2}{*}{ NT } \\
\hline & investigated & positive & $\begin{array}{l}\text { enterica } \\
\text { (I) }\end{array}$ & $\begin{array}{l}\text { salamae } \\
\text { (II) }\end{array}$ & $\begin{array}{c}\text { arizonae } \\
\text { (IIIa) }\end{array}$ & $\begin{array}{l}\text { diarizonae } \\
\text { (IIIb) }\end{array}$ & $\begin{array}{c}\text { houtanae } \\
\text { (IV) }\end{array}$ & $\begin{array}{c}\text { indica } \\
\text { (VI) }\end{array}$ & \\
\hline \multicolumn{10}{|l|}{ Family Gerrhosauridae } \\
\hline Gerrhosaurus flavigularis & 1 & 1 & 1 & 0 & 0 & 0 & 0 & 0 & 0 \\
\hline Gerrhosaurus nigrolineatus & 1 & 0 & 0 & 0 & 0 & 0 & 0 & 0 & 0 \\
\hline Gerrhosaurus validus & 2 & 1 & 0 & 0 & 0 & 0 & 0 & 0 & 1 \\
\hline Zonosaurus maximus & 1 & 0 & 0 & 0 & 0 & 0 & 0 & 0 & 0 \\
\hline \multicolumn{10}{|l|}{ Family Iguanoidae } \\
\hline Brachylophus fasciatus & 1 & 0 & 0 & 0 & 0 & 0 & 0 & 0 & 0 \\
\hline Cyclura nubila & 1 & 1 & 1 & 0 & 0 & 0 & 0 & 0 & 0 \\
\hline Iguana iguana & 29 & 13 & 3 & 0 & 0 & 0 & 10 & 0 & 0 \\
\hline Sauromalus obesus & 1 & 0 & 0 & 0 & 0 & 0 & 0 & 0 & 0 \\
\hline \multicolumn{10}{|l|}{ Family Lacertidae } \\
\hline Podarcis sicula & 3 & 0 & 0 & 0 & 0 & 0 & 0 & 0 & 0 \\
\hline \multicolumn{10}{|l|}{ Family Phrynosomatidae } \\
\hline Sceloporus malachiticus & 3 & 1 & 0 & 1 & 0 & 0 & 0 & 0 & 0 \\
\hline \multicolumn{10}{|l|}{ Family Polychrotidae } \\
\hline Anolis equestris & 2 & 1 & 1 & 0 & 0 & 0 & 0 & 0 & 0 \\
\hline Anolis sagrei & 1 & 0 & 0 & 0 & 0 & 0 & 0 & 0 & 0 \\
\hline Anolis barbatus & 1 & 0 & 0 & 0 & 0 & 0 & 0 & 0 & 0 \\
\hline \multicolumn{10}{|l|}{ Family Scincidae } \\
\hline Eumeces schneideri & 1 & 0 & 0 & 0 & 0 & 0 & 0 & 0 & 0 \\
\hline Eumeces schneideri & 1 & 0 & 0 & 0 & 0 & 0 & 0 & 0 & 0 \\
\hline $\begin{array}{l}\text { Trachylepis (Mabuya) } \\
\text { quinquetaeniata }\end{array}$ & 1 & 0 & 0 & 0 & 0 & 0 & 0 & 0 & 0 \\
\hline Tiliqua rugosa & 1 & 0 & 0 & 0 & 0 & 0 & 0 & 0 & 0 \\
\hline Tiliqua scincoides & 1 & 1 & 0 & 0 & 0 & 0 & 0 & 0 & 1 \\
\hline \multicolumn{10}{|l|}{ Family Teiidae } \\
\hline Ameiva ameiva & 1 & 0 & 0 & 0 & 0 & 0 & 0 & 0 & 0 \\
\hline \multicolumn{10}{|l|}{ Family Varanidae } \\
\hline Varanus exanthematicus & 11 & 3 & 1 & 1 & 0 & 0 & 0 & 0 & 1 \\
\hline Varanus salvadorii & 1 & 0 & 0 & 0 & 0 & 0 & 0 & 0 & 0 \\
\hline Varanus salvator & 3 & 1 & 0 & 1 & 0 & 0 & 0 & 0 & 0 \\
\hline Total & 374 & 122 & 72 & 20 & 0 & 4 & 20 & 1 & 5 \\
\hline
\end{tabular}

NT - non-typeable

were detected in 86 of 159 (54.1\%) faecal reptile samples, mostly in lizards and snakes. However, it was only detected in one sample from a single turtle out of 38 turtles investigated (Geue and Löschner 2002). In the present study, high percentage of Salmonella positive samples in chelonians was shown. This is consistent with the findings from a study by Nowakiewicz et al. (2012) where Salmonella were isolated from 15 to $80(18.75 \%)$ tortoises investigated in Poland. Moreover, in Italy Salmonella spp. were isolated from 81 of $220(36.8 \%)$ and from 17 of $67(25.4 \%)$ cloacal swabs collected from $T$. graeca and T. hermanni tortoises, respectively (Percipalle et al. 2011). These findings confirm that tortoises can be considered a reservoir for Salmonella. The high percentage of Salmonella among lizards and snakes is consistent with the results of other investigators (Mermin et al. 1997; Kuroki et al. 2013; Krautwald-Junghanns et al. 2013; Sting et al. 2013). 
Salmonella was frequently found in the green iguana (Iguana iguana) and bearded dragon (Pogona vitticeps) (Geue and Löschner 2002), as shown in our study by 13 out of 29, and 13 out of 25, respectively. In Poland, popularity of the green iguana and bearded dragon increases year after year and those two species of reptiles are becoming very popular as pet reptiles. Taking together, this study suggests that the prevalence of Salmonella spp. in reptiles in Poland does not vary considerably between the species of reptiles tested but we have found that some species of reptiles may carry the Salmonella more frequently (e.g. Iguana iguana, Pogona vitticeps, Morelia viridis) than others (Physignathus cocincinus, Boa constrictor).

All serotypes detected in this study were non-typhoidal. Those serotypes of Salmonella may lack pathogenicity in reptiles but they can be responsible for severe invasive infections, especially in infants, elderly or immunocompromised individuals (Van Meervenne et al. 2009). Almost $60 \%$ of Salmonella positive samples from reptiles belong to the species Salmonella enterica subsp. enterica. This serovar of Salmonella was also found to be predominant by other investigators (Pedersen et al. 2009; Percipalle et al. 2011; Nowakiewicz et al. 2012; Marin et al. 2013). Pasmans et al. (2005) examined 44 serotypes of Salmonella enterica from pet reptiles and found that all were able to invade human intestinal epithelial cells and could cause a disease, depending on the age of individual and their immune status. It was also shown in this study that $S$. enterica subs. salamae and $S$. enterica subs. houtanae were the second most frequently common serovars of Salmonella. Interesingly, S. enterica subs. salamae was recorded especially in snakes whereas $S$. enterica subs. houtanae was detected in lizards and not in snakes. This may reflect different ecological behaviours and feeding habits. However, based on the results obtained by others investigators (Kuroki et al. 2013; Krautwald-Junghanns et al. 2013; Marin et al. 2013; Pasmans et al. 2005; Sting et al. 2013) it is difficult to state exactly what kinds of $S$. enterica subspecies are rarely isolated from reptiles, from which other uncommon Salmonella subspecies are often isolated. This huge serovars sectrum of Salmonella strains isolated from reptiles may pose a hazard to human health because it is difficult to predict which kind of Salmonella enterica may be carried in a particular reptile pet. Moreover, the diagnosis of reptile-associated human salmonellosis may pose substantial challenges for laboratories in those countries where the controls program are not applied as a routine procedure. For instance, Pedersen et al. (2009) have shown that most of the serovars detected are called, usually, exotic serotypes, and many do not have a common name. This study confirmed that multiplex PCR assay is rapid, specific and easy to perform, and could be a simple tool for Salmonella detection and characterisation. This assay is therefore well adapted for rapid screening of large numbers of samples.

In conclusion, the detection of Salmonella in pet reptiles in Poland confirms that those animals are potential carriers of the bacteria. The incidence of Salmonella detected in this study was moderate (32.6\%). Nevertheless, all of the serovars are capable of causing clinical infections in human. That is why appropriate hygienic conditions should be recommended for the handling of reptiles and their trade should be monitored. It could also be of importance to apply Salmonella control programmes for reptiles in Poland. In addition, multiplex PCR provides a rapid, sensitive and cost-effective detection assay.

\section{Acknowledgements}

This research was supported by the Polish Ministry of Education and Science (grant no. N308 036 32/3369).

\section{References}

Aabo S, Rasmussen OF, Rossen L, Sorensen PD, Olsen JE 1993: Salmonella identification by polymerase chain reaction. Mol Cell Probes 7: 171-178 
Center for Disease Control and Prevention 2013: Eight multistate outbreaks of human Salmonella infections linked to small turtles - United States, 2013. Center for Disease Control and Prevention Web site. Available at: www.cdc.gov/salmonella/small-turtles-03-12/index.html. Posted October 18, 2013.

EN ISO 6579:2003/A1:2007 Microbiology of food and animal feeding stuffs. Horizontal method for the detection of Salmonella spp. (ISO 6579:2003). Standard by UNE-EN ISO, 2003.

European Food Safety Authority (EVSA) 2013: The European Union summary report on trends and sources of zoonoses, zoonotic agents and food-borne outbreaks in 2011. EFSA Journal, 11: 3129

Friedman CR, Torigian C, Shillam PJ, Hoffman RE, Heltzel D, Beebe JL, Malcolm G, De Witt WE, Hutwagner L, Griffin PM 1998: An outbreak of salmonellosis among children attending a reptile exhibit at a zoo. J Pediatr 132: $802-807$

Geue L, Löschner U 2002: Salmonella enterica in reptiles of German and Austrian origin. Vet Microbiol 84: 79-91

Haedicke W, Wolf H, Ehret W, Reischl U 1996: Specific and sensitive two-step polymerase chain reaction assay for the detection of Salmonella species. Eur J Clin Microbiol Infect Dis 15: 603-607

Hoszowski A, Wasyl D 2002: Salmonella serovars found in animals and feeding stuffs in 2001 and their antimicrobial resistance. Bull Vet Inst Pulawy 46: 165-178.

Johnson-Delaney CA 1996: Reptiles zoonoses and threats to public health. In: Mader DR (Ed.): Reptile Medicine and Surgery. PA: WB Saunders Company, Philadelphia, pp: 20-33

Krautwald-Junghanns ME, Stenkat J, Szabo I, Ortlieb F, Blindow I, Neul AK, Pees M, Schmidt V 2013: Characterization of Salmonella isolated from captive and free-living snakes in Germany. Berl Munch Tierarztl Wochenschr 126: 209-215

Kuroki T, Ishihara T, Furukawa I, Okatani AT, Kato Y 2013: Prevalence of Salmonella in wild snakes in Japan. Jpn J Infect Di. 66: 295-298

Lakew W, Girma A, Triche E 2013: Salmonella enterica serotype arizonae meningitis in a neonate. Case Rep Pediatr 813495

Lee K, Iwata T, Shimizu M, Taniguchi T, Nakadai A, Hirota Y, Hayashidani H 2009: A novel multiplex PCR assay for Salmonella subspecies identification. J Appl Microbiol 107: 805-811

Marin C, Ingresa-Capaccioni SS, González-Bodi F, Marco-Jiménez S, Vega S 2013: Free-living turtles are a reservoir for Salmonella but not for Campylobacter. PLoS One 8: e72350

Mermin J, Hoar B, Angulo FJ 1997: Iguanas and Salmonella marina infection in children: a reflection of the increasing incidence of reptile-associated salmonellosis in the United States. Pediatrics 99: 399-402

Mermin J, Hutwagner L, Vugia D, Shallow S, Daily P, Bender J, Koehler J, Marcus R, Angulo FJ 2004: Emerging infections program food net working group. Reptiles, amphibians, and human Salmonella infection: a population-based, case-control study. Clin Infect Dis 15: 253-261

Nowakiewicz A, Ziółkowska G, Zięba P, Stępniewska K, Tokarzewski S 2012: Russian tortoises (Agrionemys horsfieldi) as a potential reservoir for Salmonella spp. Res Vet Sci 92: 187-190

Pasmans F, Martel A, Boyen F, Vandekerchove D, Wybo I, Immerseel FV, Heyndrickx M, Collard JM, Ducatelle R, Haesebrouck F 2005: Characterization of Salmonella isolates from captive lizards. Vet Microbiol 110: 285-291

Pedersen K, Lassen-Nielsen AM, Nordentoft S, Hammer AS 2009: Serovars of Salmonella from captive reptiles. Zoonoses Public Health 56: 238-242

Percipalle M, Giardina G, Lipari L, Piraino C, Macrì D, Ferrantelli V 2011: Salmonella infection in illegally imported spur-thighed tortoises (Testudo graeca). Zoonoses Public Health 58: 262-269

Sting R, Ackermann D, Blazey B, Rabsch W, Szabo I 2013: Salmonella infections in reptiles--prevalence, serovar spectrum and impact on animal health. Berl Munch Tierarztl Wochenschr 126: 202-208

Van Meervenne E, Botteldoorn N, Lokietek S, Vatlet M, Cupa A, Naranjo M, Dierick K, Bertrand S 2009: Turtleassociated Salmonella septicaemia and meningitis in a 2-month-old baby. J Med Microbiol 58: 1379-81

Weinstein JW, Seltzer EG, Nelson RS 1995: Reptile associated salmonellosis-selected states, 1994-1995. MMWR Morb Mortal Wkly Rep 44: 347-350

Willis C, Wilson T, Greenwood M, Ward L 2002: Pet reptiles associated with a case of salmonellosis in an infant were carrying multiple strains of Salmonella. J Clin Microbiol 40: 4802-4803

Woodward DL, Khakhria R, Johnson WM 1997: Human salmonellosis associated with exotic pets. J Clin Microbio 35: 2786-2790

Zając M, Wasyl D, Hoszowski A, Le Hello S, Szulowski K 2013: Genetic lineages of Salmonella enterica serovar Kentucky spreading in pet reptiles. Vet Microbiol 166: 686-689 